\title{
Raiders to Traders? Economics of Integration among Nomadic Communities in North Africa
}

\author{
Wim Broekaert and Wouter Vanacker
}

\section{1 \\ Introduction}

Since the Augustan age, Rome progressively moved away from the North African coastline into the dusty inlands. To the various (semi)nomadic tribes pasturing their flocks within and beyond the Roman range of power, Rome's arrival entailed various political, economic and social consequences. The presence of Roman hegemony in particular had important repercussions for the traditional power balance and the nature of exchange between sedentary and (semi-)nomadic groups. While the restrictions of a pastoral economy had previously been met by raiding, pillaging and the exaction of tribute, Roman occupation provided a political and socio-economic framework which allowed alternative solutions. It has been argued before that the economic interaction between nomadic and sedentary societies cannot be reduced to hostility and predation but is also characterized by close symbiosis and interdependency. ${ }^{1}$ In this contribution however, we show that previous research seriously underestimated the intermediary role of nomads in supplying both Roman civic and military settlements and the sub-Saharan kingdoms. Pastoralist nomadic tribes duly recognized the economic potential of emerging and ever-expanding civil and military markets and took advantage of these economic opportunities by playing an important role as very mobile commercial mediators connecting the Mediterranean and the sub-Saharan regions. To analyze these patterns of exchange during the Roman imperial period, we will first present an anthropological model of interaction between nomadic and settled communities and the economic opportunities for both parties. Next, we test the applicability of the model by discussing the particular role of the Garamantes in the economy of Roman Africa. To corroborate the analysis, data on economic interaction

1 Wouter Vanacker, "Differentiated Integration Trajectories of the Nomadic Population in Roman North Africa (1st-3rd cent. AD)," in: Integration in Rome and in the Roman World. Proceedings of the Tenth Workshop of the International Network Impact of Empire (Lille, June 23-25, 2011), Stéphane Benoist, Gerda De Kleijn (eds.) (Leiden/Boston, 2013), pp. 197-216. 
with local tribes in other Roman frontier zones and, above all, anthropological research of other pre-industrial pastoral economies will be adduced to offer comparative evidence.

\section{Pastoral Nomadism(s) in North Africa}

Over the centuries, northern Africa has witnessed different types of pastoral nomadism or semi-nomadism. Contrary to common belief, these nomads do not live permanently "under the tent": they frequently migrate to herd their flocks but return to the same base camp for a certain period of the year. In mountainous regions, environmental restrictions even further reduce migrations to limited transhumance. Only the desert and pre-desert witnessed the development of modes of highly mobile pastoral nomadism with comparably less engagement in agriculture, often however being counterbalanced by a more pronounced engagement in (mediatory) trade. ${ }^{2}$ The highly differentiated environmental features of the region, characterized by the alteration of mountains, plains and desert, hence caused a plethora of migration patterns to develop. Johnson recognized at least five forms of pastoral migration in North Africa, each presenting certain peculiarities in herd composition and a specific multi-resource economic strategy. ${ }^{3}$ At least in modern times, pastoral nomadism is best described in terms of differentiation and diversity.

The question is whether this contemporary model of African pastoral nomadism can be applied to Roman times? Traditional literary evidence usually does not allow a systematic approach and subdivision in ideal types as proposed in modern anthropology and ethnography. Apart from considering the nomadic societies with contempt, Greek and Roman accounts generally fail to provide even the basic information required for a thorough analysis and characterization of the internal social, economic and governing institutions. ${ }^{4}$ Moreover,

2 See Jeffrey C. Kaufmann, "The Sediment of Nomadism," History in Africa 36 (2009), pp. $235^{-264}$.

3 Douglas L. Johnson, The Nature of Nomadism. A Comparative Study of Pastoral Migrations in Southwestern Asia and Northern Africa (Chicago, 1969), pp. 170-176.

4 On the Greek and Roman perception of nomadism, see Pol Trousset, "Villes, campagnes et nomadisme dans l'Afrique du Nord antique: représentations et réalités," in Villes et campagnes dans l'empire romain. Actes du Colloque organisé par l'U.E.R. d'Histoire, Paul A. Février, Philippe Leveau (eds.) (Aix-en-Provence, 1980), pp. 195-206; Georges Devallet, "Vagi, palantes Afri: quelques réflexions sur l'image romaine du nomade africain," in Histoire des Hautes Steppes. Antiquité-Moyen Âge, Bejaoui, Fathi (ed.) (Sbeitla, 2001) pp. 31-38; Maurice Sartre, "Les nomades dans l'Empire romain," in Le monde de l'itinérance en Méditerranée de 
ancient authors tend to reduce the pastoralist community to a stereotype of savage nomads and pillagers, with no interest whatsoever in agriculture and other aspects of sedentary societies. Tacitus' description of the Musulamii as a warmongering tribe of rogues is a good example. ${ }^{5}$ Fortunately, the one-sided nature of literary sources can now be challenged by more multifaceted archaeological datasets. Archaeological surveys suggest that peoples, who were dwelling in the North African inlands and had been described as highly mobile and non-sedentary nomadic tribes in literary sources, should actually be considered semi-nomadic groups. The ruins of the civitas Tigensium for instance have been identified as the remains of a fortified settlement of semi-nomads predating Roman occupation. ${ }^{6}$ The remains offer an idea of what could have been the 'nomadic' fortifications (pyrgoi, turres, and castella) mentioned in literary sources. ${ }^{7}$ In a similar vein, semi-nomads appear to have occupied large farmsteads with big herd enclosures for sheep and goats, but also for camels and

l'antiquité à l'époque moderne. Procédures de contrôle et d'identification, eds. Claudia Moatti, Wolfgang Kaiser, and Christophe Pébarthe (Bordeaux, 2009), pp. 58-6o; Brent D. Shaw, "Fear and Loathing: the Nomad Menace and Roman Africa," in Roman Africa (The Vanier Lectures), ed. Colin M. Wells (Ottawa, 1982), pp. 29-31; Brent D. Shaw, "Eaters of Flesh, Drinkers of Milk': the Ancient Mediterranean Ideology of the Pastoral Nomad," Ancient Society 13/14 (1982-1983); Yves A. Dauge, Le barbare: recherches sur la conception romaine de la barbarie et de la civilisation (Bruxelles, 1981), pp. 620-626; Pol Trousset, "Limage du nomade saharien dans l'historiographie," Production pastorale et société 10 (1982), pp. 101-102.

5 Cf. Tac. Ann. 2, $5^{2}$.

6 Pol Trousset, "Thiges et la civitas Tigensium," in Actes du colloque organisé par l'École française de Rome sous le patronage de l'Institut national d'archéologie et d'art de Tunis, s.e., (Rome, 1987), pp. 143-167. Also see Naidé Ferchiou, "Habitats fortifiés pré-impériaux en Tunisie antique," Antiquités africaines 26 (1990), pp. 43-86. Cf. the famous description of the oasis of Tacape: Plin. N.H. 18, 51.

7 Castella: Sall. Bell. Iug. 87, 1 + 92, 5: castellum near the Mulucha river and 93, $3+6$ and 94, 3-4. These castella have also been mentioned by Pliny: Plin. N.H. 5, 1. Turres: Sall. Bell. Jug. 103, 1. Oppida: Sall. Bell. Iug. 46, 5 + 87, 1, also 89, 4 + 91, 4-9: Numidian "oppidum" Capsa; 81, $2+88$, 3 \& 21, 2 \& 101, 1 \& 102, 1: oppidum Cirta; 12, 3: oppidum Thirmida. 29, 4 and 47, 1+66, 2-3 +67, 1-3 + 68,3: oppidum Vaga; 37, 3: oppidum Suthul; arx/oppidum Zama: 56, 1/57, 1 + 59, 1 + 6o, 1 + 61, 1; oppidum Sicca (Veneria) 56, 3. Cf. finally 75, 1 + 77,1: oppidum Thala; 90,2: oppidum Laris; 100, 1: oppidis maritumis; 89, 1: oppida castellaque; 92, 3: alia oppida. Urbes: Sall. Bell. Iug. 29, 7 and 61, 1. Cf. also Verg. Aen. 4, 40-43. Diod. Sic. 3, 49 for pyrgoi as storages near sources of water. Also see the account of Caesar's African War: Bell. Afr. 2-7 (oppida and castella) and 25: on an oppidum of the Gaetulians and Cirta called the wealthiest town of the region. During the war, fields were stripped, strongholds and towns destroyed: Bell. Afr. 26. 
even cattle, pigs and horses. ${ }^{8}$ This kind of evidence has now confirmed that an oversimplified image of two mutually exclusive and incompatible worlds, viz. sedentary agriculture and pastoral nomadism, simply does not correspond to African society in Roman times. ${ }^{9}$ Nevertheless, many historians closely following the biased nature of Latin literature have failed to perceive the essentially heterogeneous character of semi-nomadic societies and economies. ${ }^{10}$

\section{3}

Interaction of Sedentary Communities and Nomads: A Model from Anthropology

Anthropological studies have shown that irrespective of the internal organization of nomadic economies, most of them are somehow (and often to a large extent) dependent on external sources of income and resources, usually procured from sedentary communities. This failure to develop an autarchic existence renders pastoral nomadic economies particularly vulnerable to temporary supply and production shocks and can lead to major reorganizations of nomadic tribal life." Various case studies have indicated that severe impoverishment can even initiate full settlement and a subsequent turn to nonpastoralist occupations. ${ }^{12}$ However, before turning to such drastic measures,

8 For instance René Rebuffat, "Recherches dans le désert de Libye," Comptes-rendus des séances de l'Académie des Inscriptions et Belles-Lettres 126, no. 2 (1982), pp. 195-197; David J. Mattingly, "New Perspectives on the Agricultural Development of Gebel and Pre-Desert in Roman Tripolitania," Revue des mondes musulmans et de la Méditerranée 41, no. 1 (1986), p. 58; René Rebuffat, "Les fermiers du désert," in L'Africa romana: atti del V convegno di studio (11-13 dicembre 1987), ed. Attilio Mastino (Sassari, 1988), p. 47f.

9 For a convincing attempt to render nomads more visible in the archaeological record, see Roger Cribb, Nomads in archaeology (Cambridge, 1991).

10 Trousset, "Villes, campagnes et nomadisme dans l'Afrique du Nord antique: représentations et réalités," p. 201; René Rebuffat and Hassan Limane, "Les confins sud de la présence romaine en Tingitane dans la région de Volubilis.," in Histoire et Archéologie de l'Afrique du Nord. Spectacles, vie portuaire, religions. Actes du Ve colloque international réuni dans le cadre du 115e Congrès national des Sociétés savantes Avignon, 1990, ed. Jehan Desanges (Paris, 1992), pp. 241-244.

11 Pavel Poucha, "Bodenbauern und Nomaden im alten Mittel- und Zentralasien," in Das Verhältnis von Bodenbauern und Viehzüchtern in historischer Sicht, ed. Irmgard Sellnow (Berlin, 1979), p. 124; A.M. Khazanov, Nomads and the Outside World (Madison, 1994), p. 122.

12 In general: Khazanov, Nomads and the Outside World, p. 83; among the Basseri in the 2oth century: Fredrik Barth, "Capital, Investment and the Social Structure of a Pastoral Nomad Group in South Persia," in Capital, Saving and Credit in Peasant Societies, 
pastoral nomads will first take recourse to various types of interaction with sedentary societies, depending on the power balance between both groups. In the context of a dominant nomadic power, resources are often obtained in predatory ways, for instance by raids on settled or other nomadic communities or through the imposition of tribute and "protection money". When power on the other hand is controlled by the sedentary community, nomads are often compelled to work as wage laborers among agriculturalists, or perform military service. ${ }^{13}$

Additionally, trade, as an economic mode of resource exchange that is less influenced by the local power balance, must be considered an important supplementary activity of many nomadic economies. The most vital incentive of exchange is the regular shortage in food supplies, even though the need for manufactured goods as well frequently stimulates interaction with settled communities. Due to technical and logistical constraints imposed by the migratory way of life, crafts and industries are usually less developed within nomadic communities, apart from occasional repairs or the production of low quality goods. ${ }^{14} \mathrm{~A}$ different way to acquire artisan products is the incorporation of settled craftsmen within the nomadic community, but these foreign artisans

eds. Raymond Firth and B.S. Yamey (London, 1964), p. 64; among the Kazakhs in the 18th century: Elizabeth E. Bacon, "Types of Pastoral Nomadism in Central and Southwest Asia," Southwestern Journal of Anthropology 10, no. 1 (1954), p. 6o; among the Kipchaks in the 12th-15th century:Ananiasz Zajackzkowski, "Das Verhältnis der nomadischen Bevölkerung zu den seßhaften Bodenbauern in der Kiptschakischen Steppe (Dest-i Kipchak) bis zum 15. Jahrhundert," in Das Verhältnis von Bodenbauern und Viehzüchtern in historischer Sicht, ed. Irmgard Sellnow (Berlin, 1979), p. 231.

13 For military service as an alternative, cf. the Al Murrah in Saudi Arabia. Donald P. Cole, "The Enmeshment of Nomads in Sa'udi Arabian Society: the Case of Al Murrah," in The Desert and the Sown. Nomads in the Wider Society, ed. Cynthia Nelson (Berkeley, 1973), p. 125 f. Hired labor as an alternative has been observed in the case of nomads involved in cotton-picking in the North White Nile region of the Sudan, cf. Abbas Mohammed, "The Nomadic and the Sedentary: Polar Complementaries—not Polar Opposites," in The Desert and the Sown. Nomads in the Wider Society, ed. Cynthia Nelson (Berkeley, 1973), p. 105. On the relations between coastal and desert Bedouin in the Western Desert in Egypt, see also Abdalla Said Bujra, "The Social Implications of Developmental Policies: a Case Study from Egypt," in The Desert and the Sown. Nomads in the Wider Society, ed. Cynthia Nelson (Berkeley, 1973), p. 147.

14 On the particularities of crafts and industries among nomads, cf. Xavier de Planhol, "Smallscale Industry and Crafts in Arid Regions," in Arid Lands: a Geographical Reappraisal, ed. Edwin S. Hills (London, 1966), pp. 273-285. 
are usually considered alien and even marginalized groups. ${ }^{15}$ Finally, trade also supplies nomadic elites with luxurious consumption goods. ${ }^{16}$ These demands often force nomads to engage in direct exchange, either selling their own products directly to city-dwellers and agriculturalists, or through the intervention of sedentary merchants. Major commercial opportunities can even influence the trajectories nomads chose for pastoral migration. However, due to restrictions imposed by migration and the difficulties in generating a regular surplus destined for the market, direct exchange frequently fails to develop into a permanent commercial system profitable for both parties. ${ }^{17}$

These practical limitations are largely met by a considerable engagement in mediatory trade, a useful concept developed by Khazanov to denote the commercial links forged by nomads between sedentary communities. ${ }^{18}$ Their mobility and experience in herding animals along far-reaching land routes allowed nomads to establish exchange connections between otherwise isolated communities, without at the same time becoming full-fledged merchants or abandoning the nomadic way of life..$^{19}$ Especially for Saharan nomads the caravan trade was for centuries the most important economic activity. The Tuareg of the Aïr for instance not merely commanded the exchange of salt, iron, ostrich feathers and other products between West and North Africa, but also organized the grain trade between desert oases and the agriculturalists of

15 See for instance the tribes of the Rif, where the lower social status of the so-called imazilen or "Shameless Ones" is based upon their engagement in blacksmithing and piping or the exercise of certain public professions (public criers, measurers and weighers in markets). See Carleton S. Coon, Tribes of the Rif(Cambridge, Mass., 1931), p. 92f. Separate castes based on occupation have been noticed in Arabian region of Southwest Asia as well. For the lower status of blacksmiths in this region, see Bacon, "Types of Pastoral Nomadism in Central and Southwest Asia," p. 64. Among the Tuareg, the ikanawen or potters and the inadan or blacksmiths form notable examples of incorporated artisan castes. Cf. de Planhol, "Small-scale Industry and Crafts in Arid Regions," pp. 278-279.

16 Jürgen Paul, "Perspectives nomades: état et structures militaires," Annales. Histoire, Sciences Sociales 59, no. 5/6 (2004), p. 1074.

17 Khazanov, "Nomads and the Outside World," pp. 202-209.

18 On nomads and mediatory trade in general, cf. Ibid., pp. 209-212. In 19th and early 2oth century Russia among the Negidals: Sergej V. Ivanov, Maksim G. Levin, and Anna V. Smolyak, "The Negidals," in The Peoples of Siberia, eds. Maksim G. Levin and Leonid P. Potapov (Chicago/London, 1964), p. 690.

19 Paul E. Lovejoy and Stephen Baier, "The Desert-Side Economy of the Central Sudan," in The Politics of Natural Disaster. The Case of the Sahel Drought, ed. Michael H. Glantz (Washington/New York/London, 1976), p. 153; V.V. Khramova, "The West-Siberian Tatars," in The Peoples of Siberia, eds. Maksim G. Levin and Leonid P. Potapov (Chicago/London, 1964), pp. 426-427. 
the southern Sahel. ${ }^{20}$ Trade stations and marketplaces were even located along migration trajectories to keep transport costs relatively low. ${ }^{21}$ The control of trade routes through the Sahara was their main political concern. In return for their mediatory participation, the nomads received slaves, manufactured goods and corn. ${ }^{22}$ Similar nomadic engagement in caravan trade (though in non-desert areas) has already been documented for antiquity, for instance among the Scythians and Sarmatian Aorsians. ${ }^{23}$

\section{$4 \quad$ Frontiers and Beyond: Mediatory Trade and the Garamantes}

The anthropological model of nomadic economies discussed above provides a valuable starting point for the discussion of exchange patterns used by nomads in Roman Africa. What effect did Roman political power have on the sedentary-nomadic power balance and, consequently, on the pastoral nomadic economy itself? How did pastoral nomadism develop under Roman rule within and beyond the frontiers? Can we trace nomadic engagement in trade, either mediatory or direct, and to what extent could this have been sparked off by the increase of settled communities and commercial opportunities in the frontier zone?

Before turning to the actual analysis of exchange patterns, two common misconceptions need to be addressed. First, the virtual absence of accounts on trans-Saharan trade in Greek and Latin literature cannot be a valuable argument to discard the possibility of large-scale commercial contacts between Roman and sub-Saharan territory. ${ }^{24}$ Archaeological studies in the Fazzan and in the sub-Sahara have shown that indigenous groups from the Sahara, such as the Garamantes, were the mediators of an ever increasing exchange between Mediterranean and sub-Saharan markets. Of major importance is the discovery of sub-Saharan goods within Garamantian territory, as well as Garamantian trade stations far to the south of the tribe's capital, exactly in places that were

\footnotetext{
20 Lovejoy and Baier, "The Desert-Side Economy of the Central Sudan," p. 15of.

21 Ibid., 152-153.

22 Irmgard Sellnow, "Der Einfluß von Nomaden auf Wirtschaft und Politik der Hausastaaten," in Das Verhältnis von Bodenbauern und Viehzüchtern in historischer Sicht, ed. Irmgard Sellnow (Berlin, 1979), pp. 194-195.

23 Her. 4, 24. Strabo 11, 5, 8.

24 Pekka Masonen, "Trans-Saharan Trade and the West African Discovery of the Mediterranean," in Ethnic Encounter and Culture Change. Papers from the Third Nordic Conference on Middle Eastern Studies, Joensuu (June 1995), ed. M'hammed Sabour, Knut S. Vikør (Bergen/London, 1997), pp. 116-142.
} 
to become important trade centers in later times. Saharan tribes indeed played an important role in connecting the estimated 5 million inhabitants of the southern pre-desert and the Sahel with the Mediterranean world. ${ }^{25}$ This evidence clearly refutes the idea of trans-Saharan trade in Roman times as "one of the most elusive myths of African history". ${ }^{26}$ Second, the establishment of a Roman frontier never really complicated or reduced exchange. It has rightly been argued that in North Africa, the frontier zone is best understood as a permeable structure designed at the control through canalization of cross-frontier (including pastoral) migrations. ${ }^{27}$ Archaeological, epigraphic and literary evidence has shown that, rather than being a 'closed frontier', the limes was continuously crossed by migrant pastoralists and traders whose goods the Romans were eager to tax. In fact, the permeability of the frontier system combined with the rise of urban and military markets effectively stimulated commercial

25 Estimated by Colin McEvedy, The Penguin Atlas of African History (Harmondsworth, 1983), p. 36 .

26 John T. Swanson, "The Myth of Trans-Saharan Trade Dring the Roman Era," The International Journal of African Historical Studies 8, no. 4 (1975), p. 582. Cf. also Mamadou L. Nabé, "Schwarzafrika südlich der Sahara und die Antike," Das Altertum 16 (1970), pp. 10-17.

27 Sebastian Matz, "Befestigung im Nirgendwo," Antike Welt 38, no. 1 (2007), pp. 55-59; René Rebuffat, "Mobilité des personnes dans l'Afrique romaine," in La mobilité des personnes en Méditerranée de l'Antiquité à l'époque moderne: procédures de contrôle et documents d'identification, ed. Claudia Moatti (Rome, 2004), pp. 156-203; Pol Trousset, "Le tarif de Zaraï: essai sur les circuits commerciaux dans la zone présaharienne," Antiquités africaines 38-39 (2002-2003), pp. 355-373; Pol Trousset, "Nouvelles barrières romaines de contrôle dans l'extrême sud tunisien," Bulletin archéologique du Comité des travaux historiques et scientifiques. Série B, Afrique du Nord 24 (1997), pp. 155-163; David J. Mattingly, Tripolitania (London, 1995), p. 79f.; Christine Hamdoune, "Géographie et administration de la Maurétanie Tingitane: ad fines imperii Romani, Mauretania Tingitana," L'information historique 53 (1991), pp. 127-133; Maurice Euzennat, Le limes de Tingitane. La frontière méridionale (Paris, 1989); Michel Janon, "Paysans et soldats," in Roman Africa (The Vanier Lectures), ed. Colin M. Wells (Ottawa, 1982), pp. 51-67; Pol Trousset, "Signification d'une frontière: nomades et sedentaires dans la zone du limes d'Afrique," in Roman Frontier Studies 1979: Papers Presented to the 12th International Congress of Roman Frontier Studies, ed. Lawrence J.F. Keppie, William S. Hanson (Oxford, 1980), pp. 931-943; Pol Trousset, Recherches sur le limes tripolitanus (Paris, 1974); Maurice Euzennat, "Recherches récentes sur la frontière d'Afrique (1964-1974), II," in Studien zu den Militärgrenzen Roms, II: Vorträge des 10. Internationalen Limeskongresses in der Germania Inferior, Xanten, 1974, eds. Dorothea Haupt, Heinz G. Horn (Xanten, 1974), pp. 429-443; Maurice Euzennat, "La frontière romaine d'Afrique," Comptes Rendus de l'Académie des Inscriptions et Belles-Lettres 134, no. 2 (1990), p. 580; Mario Liverani, "Imperialismo, colonizzazione e progresso tecnico. Il caso nel Sahara libico in età romana," Studi storici 47, no. 4 (2006), p. 1033. 
exchange with Saharan peoples. These developments will be discussed in more detail in the following sections, by focusing on the Garamantian economy as a case study.

Traditionally, the Garamantian pastoral economy has been described as dominating the trans-Sahara trade between Roman territory in the north and African kingdoms in the south. ${ }^{28}$ In this triangular trade pattern, it has frequently been argued that the Garamantes focused on exporting salt to the subSaharan area in exchange for gold and slaves, who allowed the use of slave labor in the Garamantian homeland but were also re-exported to Roman markets, and importing Mediterranean ceramics, glassware and food in return. ${ }^{29}$ This model however covers only part of the Garamantian economy and neglects both the export potential of locally produced wares well-documented in the archaeological records and their crucial role as mediatory traders. Far more commercial opportunities in the southern and northern markets therefore need to be taken into account. The following sections will discuss several markets the Garamantes were supplying and the sometimes remarkable range of goods. As literary sources usually are silent about the nature of merchandise being transported by nomadic peoples and epigraphy offers only little help, we explore the various opportunities available to the Garamantes and adduce comparative evidence, both from antiquity and other nomadic societies, to add weight to our analysis.

28 D.J. Mattingly, ed. The Archaeology of Fazzān. Vol. I. Synthesis (Tripoli, 2003), p. 277.

29 Cf. Robin C.C. Law, "The Garamantes and Trans-Saharan Enterprise in Classical Times," The Journal of African History 8, no. 2 (1967), p. 195; Mario Liverani, "The Libyan Caravan Road in Herodotus IV.181-185," Journal of the Economic and Social History of the Orient 43, no. 4 (2000), pp. 507-508; Mario Liverani, "The Garamantes: a Fresh Approach," Libyan Studies 31 (2000), p. 20; Liverani, "Imperialismo, colonizzazione e progresso tecnico. Il caso nel Sahara libico in età romana," p. 1019; David J. Mattingly, "Twelve Thousand Years of Human Adaptation in Fezzan (Libyan Sahara)," in The Archaeology of Drylands. Living at the Margin, eds. Graeme Barker, David Gilbertson (London/New York, 2000), p. 172; Efthymia Nikita, David Mattingly, and Marta M. Lahr, “Sahara: Barrier of Corridor? Nonmetric Cranial Traits and Biological Affinities of North African Late Holocene Populations," American Journal of Physical Anthropology 147 (2011), p. 280; Andrew Wilson, "The Spread of Foggara-based Irrigation in the Ancient Sahara," in The Libyan Desert: Natural Resources and Cultural Heritage, eds. David J. Mattingly et al., (London, 2006), p. 206. 


\section{$5 \quad$ The Military Market}

The triangular trade pattern discussed above severely underestimates the opportunities offered by the military supply to Roman garrisons (see Figure 6.1 and Figure 6.2). It is well-known from the ostraca discovered in Bu Njem that the Garamantes were providing barley, mules and donkeys to the Roman garrisons. ${ }^{30}$ Yet, considering the specific production in the Garamantian kingdom and the frequent interaction between the Roman military and pastoral nomads, it seems very likely the supply of merchandise was not confined to these products alone. Local tribes must have recognized the economic advantages of the continuing soldierly demand and the proximity of a rather stable market. The picture emerging from the Bu Njem ostraca indeed suggests recurrent contacts and a more than superficial acquaintance of the Roman garrison with the native tribes along the frontier zone.

Several ostraca document how soldiers were being dispatched to a nearby customs house (statio camellariorum), where they offered assistance in collecting the tax camel drivers were obliged to pay. ${ }^{31}$ Their continued presence in this essentially civil context of frontier economies no doubt stimulated a certain

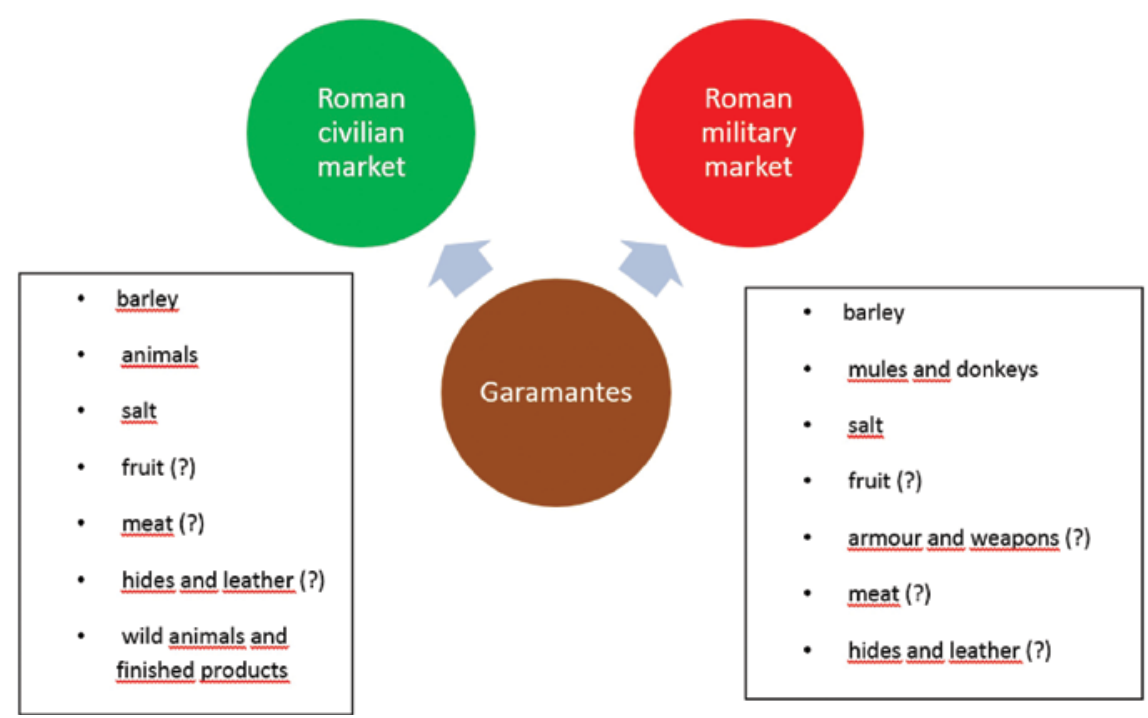

FIGURE 6.1 Export to northern regions.

$30 \quad$ O. Bu Njem $71-72$.

31 O. Bu Njem 3-5; 8-10 and 42. See Robert Marichal, Les ostraca de Bu Njem (Tripoli, 1992), pp. 112-113. It should be noted however that statio can also refer to a unit of camel riders, 


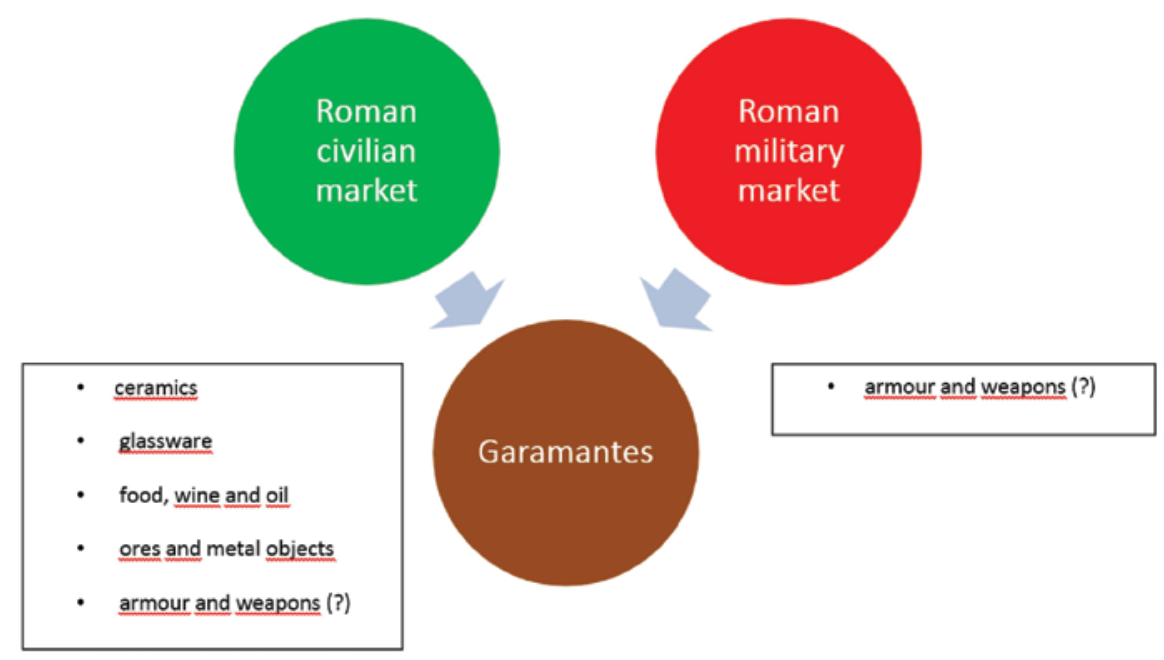

FIGURE 6.2 Imports from northern regions.

familiarity with the camellarii, especially because the dates on the ostraca indicate that caravans were passing through the customs house on a regular basis, viz. once every two days. This familiarity is reflected in another series of ostraca, indicating that the Roman military was regularly making use of the transport services offered by the native camellarii. ${ }^{32}$ Particularly interesting is the fact that measures of the imported goods are often cited in native languages and that different indigenous names are used for a single unit. Apparently the origin of the camellarius and his mother tongue determined the specific terminology, implying not only that the military relied on the services of different tribes, but also that the soldiers of the garrison were sufficiently acquainted with these local measures to use them in administrative documents. The latter clearly points to the frequency of interactions. The Garamantian caravans were also involved in the diffusion of information, for one ostracon reports that they had brought letters to the garrison. ${ }^{33}$ The nature of these litterae is still debated on. Marichal assumes they may have been letters of recommendation, written

which completely alters the meaning of the ostracon. A similar reference is found in P. Mich. Inv. 2758 \& 2761 .

32 O. Bu Njem $76-81$ and 88. Ibid., 100-101. The camel drivers have either Punic (Iddibal and Macargus) or Libyan (Iassuchtan and Iaremaban) names. Johannes Kramer, Vulgärlateinische Alltagsdokumente auf Papyri, Ostraka, Täfelchen und Inschriften, vol. 23 (Berlin/New York, 2007), pp. 76-77. 
by officers from a neighboring garrison, for he claims it would be odd to entrust the Garamantes with confidential correspondence. ${ }^{34}$ However, as the ostraca discussed above clearly indicate that the military frequently made use of the services offered by the Garamantian caravans, one may wonder whether the camellarii still needed an introduction. Moreover, would this kind of letters be mentioned in an ostracon as part of the garrison's administration? Entrusting letters to the Garamantian camel drivers may quite easily be the simplest solution to quickly diffuse information. Especially when the content of the letters does not discuss military affairs or decision-making, these could without much 'danger' be entrusted to the Garamantes. We only have to consider some of the letters discovered in Vindolanda to get an idea of the fairly innocent correspondence passing through military camps, such as the invitation to a birthday party or the request to send some hunting nets. ${ }^{35}$

A final aspect of the continuing interaction shows a Roman soldier escorting Garamantes. ${ }^{36}$ The exact purpose is still unclear. Did the military hope to start negotiations with Garamantian tribes? Or were soldiers obliged to accompany people who were living outside the frontier upon entrance within the empire, as described by Tacitus and Dio Cassius? ${ }^{37}$ If the latter were true and Garamantian and other pastoralists' caravans were constantly crossing the border to do business, then the soldiers of Bu Njem must have familiarized very quickly with the caravan people. The close involvement of the Roman beneficiarii in monitoring customs as indicated by the Lambaesis tariff also points to regular interaction between the military and pastoralists frequenting local markets. ${ }^{38}$

Thus, the many opportunities for personal contact and continuous interaction must have created a mental environment of trust and familiarity and hence stimulated economic exchanges between the pastoralist communities and the Roman military. This is not a particularly earth-shattering observation, as comparative evidence from the northern frontier zone similarly identifies the involvement of the Roman military in cross-frontier exchange. In Pannonia superior for instance, a centurio of the $15^{\text {th }}$ legion acting as an interpreter and merchant most likely organized the import of merchandise produced by tribes

34 Marichal, Les ostraca de Bu Njem: 111.

35 Vindolanda tablet 291 and 233 respectively.

$36 \quad$ O. Bu Njem 28.

37 Tac. Ann. 4, 64; Dio Cass. 73, 2, 4. See also Augustinus Ep. 46.

$38 \quad A E$ 1914, 234. 
living across the border and unfamiliar with Latin language. ${ }^{39}$ We therefore argue that the commercial contacts between the frontier garrisons and tribal communities outside the empire were probably far more intense than textual and archaeological sources allow us to detect. We now focus on the various goods the Garamantes may have supplied to the Roman military.

First, industrial residues from the Jarma area and other areas of the Fazzan have identified a thriving salt extraction industry, producing one of the key commodities of the traditional model of exchange. ${ }^{40}$ Salt however was not only in demand in the southern sub-Saharan kingdoms, but could also be exported to the northern markets, as salt was a main ingredient of the military diet. It added flavor to various meals and facilitated food storage by reducing perishability of a wide range of victuals such as meat, fish and vegetables. Moreover, salt belonged to the soldiers' rations supplied by the military, so merchants specializing in this particular product were always certain to find a stable and predictable market. ${ }^{41}$ Because of these favorable trading conditions, salt production and commerce was very often located in the near vicinity of frontier zones. Along the northern limes for instance, salt extraction has been documented along the Belgian and southern English coastline. ${ }^{42}$ Distribution to the military markets was organized by the Morini and Menapii in particular, for salt-dealers belonging to these tribes initiated two honorary inscriptions for L. Lepidius Proculus, a centurio primuspilus who had served in Neuss, a military settlement along the Rhine frontier. ${ }^{43}$ It seems very likely they had been supplying his garrison with salt. Evidence of maritime and riverine salt trade is supplied by a range of dedicatory inscriptions of salt-dealers found near Colijnsplaat, a sanctuary situated in the Scheldt estuary and dedicated

$39 A E$ 1978, 635. See Titus Kolník, "Q. Atilius Primus, interpres centurio und negotiator. Eine bedeutende Grabinschrift aus dem 1. Jh. u. Z. im quadischen Limes-Vorland," Acta Archaeologica Academiae Scientiarum Hungaricae 30 (1978), pp. 61-75. Mattingly, The Archaeology of Fazzān. Vol. I. Synthesis, pp. 118 and 359. Ground stone tools found in Garamantian settlements were possibly used to crush blocks of salt. Lucia Mori, "The Ground Stone Tools," in Aghram Nadharif. The Barkat Oasis (Sha'Abiya of Ghat, Libyan Sahara) in Garamantian Times, ed. Mario Liverani (Firenze, 2005), p. 284.

41 S. Perea Yébenes, "El uso de la sal en el ejército romano y su abastecimiento en época altoimperial," in Arqueología militar romana en Hispania II : producción y abastecimiento en el ámbito militar, ed. A. Morillo Cerdán (León, 2006), pp. 354-359.

42 Curtis, Robert I. Garum and Salsamenta: Production and Commerce in Materia Medica (Leiden, 1991), pp. 79-80; Hugo Thoen, "Zoutwinning: de teloorgang van een antieke industrie langs de Vlaamse Kust," in Met zicht op zee, ed. Jean-Luc Meulemeester (Tielt, 2000), pp. 11-14.

$43 \quad C I L 11,390-391$. 
to the indigenous goddess Nehalennia. ${ }^{44}$ She was worshipped in particular by businessmen crossing the Channel and sailing the North Sea, the Rhine and Scheldt during the late 2nd and early 3 rd century and organizing the supply of British and German military markets. ${ }^{45}$ A very similar trading pattern may have developed along the African frontier. As we have no evidence of salt production in the settlements close to the limes, salt refined in Garamantian territory may well have been a major import product. Literary sources confirm the material evidence of salt production in the Sahara and among the Garamantes in particular. ${ }^{46}$

Yet, salt may not have been the only ingredient of the military diet produced and exported by the Garamantes. One of the Bu Njem ostraca notes the arrival of a donkey laden with suriacas. ${ }^{47}$ In the first edition, Marichal identified this merchandise as Syrian textiles, without however offering an explanation for his suggestion or contextualizing the presence of Syrian goods on the southern African limes. ${ }^{48}$ One may rightly wonder how and why these goods had ended up among the merchandise transported by a pastoralist caravan and which customers they were hoping to find in a military garrison. More recent accounts of the African caravan economy equally struggled with this remarkable document, but adhered to Marichal's interpretation. ${ }^{49}$ Nevertheless, a fragment of Pliny's Natural History can help to elucidate the word suriacas or at least present a more plausible interpretation. In his description of trees, Pliny mentions the myrobalanum, a tree commonly found in Arabia, the Thebais and the land of the Troglodytae, viz. an African region very close to the Garamantian territory. ${ }^{50}$ The fruit has been identified as the behen or ben nut, the fat and soft kernel of which can be consumed, but is far more frequently used for oil extraction, as indicated by its unequivocal scientific name Moringa oleifera. Interestingly, Pliny adds that the Arabian kind was called syriaca. If this name also applied to the African variety, which admittedly Pliny fails to specify, then the ostracon would merely record the import of a locally produced fruit as an addition to the military diet. As Pliny in another fragment

\footnotetext{
$44 \quad A E$ 1973, 362; $A E$ 1973, 364 and $A E$ 1973, 378.

45 Petrus Stuart and Julianus E. Bogaers, Nehalennia, Römische Steindenkmäler aus der Oosterschelde bei Colijnsplaat (Leiden, 2001).

46 Cf. the many attestations in Herodotos: Her. 4, 181-185 and especially 183 among the Garamantes. Plin. N.H. 5, 34 .

$47 \quad$ O. Bu Njem 73.

48 Marichal, "Les ostraca de Bu Njem," p. 111.

49 Mattingly, "Tripolitania," p. 157. "a consignment of cloth (syriacas) though both its origin and destination are unclear".

$50 \quad$ Plin. N.H. 12, 101.
} 
lauds the lusciousness of fruits and other crops cultivated by the Garamantes and botanical remains are now able to corroborate his descriptions, it seems at least possible that the Garamantes were supplying the garrison with fresh fruits. ${ }^{51}$ Moreover, significant fruit cultivation by the Garamantes is also suggested by the manifold discoveries of date stones and other fruit remains in funerary contexts in the Wadi al'Ajal (Zinkekra cemetery), while the regional consumption of dates is further affirmed by the presence of date pits in waste contexts at Ghirza, Aghram Nadharif and in the grave chamber of the Abalessa monument. ${ }^{52}$

Next, various sites in the Fazzan, and Saniat Jibril in particular, have yielded archaeological evidence of metalworking, such as iron slags, copper-alloy fragments, ingot molds and hearths. ${ }^{53}$ The Garamantes clearly disposed of iron and copper ore and seem to have produced a variety of domestic products and tools. Yet, we cannot exclude that part of the production of metal objects was also aimed at military markets. So far, we have no evidence of Garamantes engaging in the production of weaponry or armor, but research of African metallurgy is

$5^{1}$ Plin. N.H. 13, 111 and David J. Mattingly, "Early Libyan State with Trans-Saharan Connections," in Money, Trade and Trade Routes in Pre-Islamic North Africa, eds. Amelia Dowler and Elizabeth R. Galvin (London, 2011), p. 53.

$5^{2}$ Zinkekra: David Mattingly et al., "Desert migrations: people, environment and culture in the Libyan Sahara," Libyan studies 38 (2007), p. 137 and 141. Ghirza: Olwen Brogan, D.J. Smith, Ghirza. A Libyan Settlement in the Roman Period (Tripoli, 1984), p. 97. Also see Plin N.H. 13, 111, on date production in the African interior up to the lands of the Garamantes. Generally, in the Tripolitanian pre-desert: Mattingly, "New Perspectives on the Agricultural Development of Gebel and Pre-Desert in Roman Tripolitania," p. 57; Rebuffat, "Les fermiers du désert," p. 56. In Aghram Nadharif: Anna Maria Mercuri et al., "The Archeobotanical Remains (Pollen, Seeds/Fruits and Charcoal)," in Aghram Nadharif. The Barkat Oasis (Sha'Abiya of Ghat, Libyan Sahara) in Garamantian Times, ed. Mario Liverani (Firenze, 2005), pp. 335-348. Abalessa monument (dated to the early fourth century AD): Gabriel Camps, "Le tombeau de Tin Hinan à Abalessa," Travaux de l'Institut de Recherches Sahariennes 24 (1965), p. 69.

53 Mattingly, "The Archaeology of Fazzān. Vol. I. Synthesis," p. 356. David J. Mattingly, ed. The Archaeology of Fazzān. Vol. II. Site Gazetteer, Pottery and Other Survey Finds (Tripoli, 2007), pp. 448-462 (overview). Mattingly, "The Archaeology of Fazzān. Vol. I. Synthesis," p. 121 (Jarma area), p. 125 (al-Hatiya oasis zone); David J. Mattingly, ed. The Archaeology of Fazzān. Vol. III. Excavations carried out by C.M. Daniels (Tripoli, 2010), p. 197 (Saniat Jibril). Also at Aghram Nadharif, see Mario Liverani, "Looking for the Southern Frontier of the Garamantes," Sahara 12 (2000), p. 43. Abalessa: Camps, "Le tombeau de Tin Hinan à Abalessa," p. 69. 
notoriously limited. ${ }^{54}$ Comparative evidence from the northern limes however confirms the existence of a lucrative trade in weapons and armor along the frontiers in addition to the production controlled by the army. ${ }^{55}$

Finally, the availability of large herds allowed the production of a wide variety of products which could be supplied to military markets. The documents from $\mathrm{Bu}$ Njem so far only refer to Garamantes importing live animals, but a range of by-products of pastoral economies may have been sold to the military as well. ${ }^{56}$ We can first imagine that part of the meat provided by slaughtered animals was being processed into salted or dried meat. As salt extraction was a main constituent of the Garamantian economy, all ingredients to allow the production and merchandizing of salted meat were present. The regular supply of meat proved to be a major opportunity for merchants, as even though the calories from animal sources were only marginal compared to cereals, meat nevertheless was included in the ancient military diet. ${ }^{57}$ Yet large-scale animal husbandry demanded less densely populated areas in which the flocks could be grazed, which may pose a problem for less fertile regions, as animals, people and arable agriculture compete for the same lands. With semi-nomadic pastoralists focusing on breeding cattle on the outskirts of the empire and beyond, the core area with the large agricultural estates had the ability to specialize in cereals and cash crops such as oil and wine and leave the supply of meat to tribes such as the Garamantes.

Moreover, pastoral economies provided for a large supply of secondary pastoral products such as hides, which could be used for leather processing, an industry which may have been particularly important to the Garamantian society as substantial quantities of alum occurred in the Fazzan. ${ }^{58}$ This specific salt was used as a mordant in the leather production process. It is obviously well-known that within a military context, demand for leather was extremely high, as it was employed for tents, armor, footwear, slings, shield covers, horse gear etc. Moreover, leather products easily wore out, which created a constant and large demand for the material. Herz for instance guesstimated that nearly

54 Copper production in the western (Akjoujt, Mauritania) and southern (Agades region) Sahara has been dated as early as the middle of the first millennium BC. John E.G. Sutton, "West African Metals and the Ancient Mediterranean," Oxford Journal of Archaeology 2 (1983), pp. 184-185.

55 R. MacMullen, "Inscriptions on Armor and the Supply of Arms in the Roman Empire," American Journal of Archaeology 64 (1960), pp. 23-40.

56 For the obvious trade in live animals, see the various species mentioned in the tariffs of Zaraï $(C I L$ 8, 4508) and Lambaesis (AE 1914, 234).

57 Roy W. Davies, "The Roman Military Diet," Britannia 2 (1971), pp. 122-142.

$5^{8}$ Mattingly, "The Archaeology of Fazzān. Vol. I. Synthesis," p. 360. 
30,000 calves or an equivalent of 70,000 goats was needed to provide a legion with sufficient leather to make tents. ${ }^{59}$ Roman military numbers present in the vicinity of the Garamantes did evidently not amount to the numbers of a legion, but according to an estimate from Vindolanda, even a small auxiliary unit still needed 3,360 goatskins for leather tents alone. ${ }^{60}$ The figures can hence offer an idea of the animal numbers required for military equipment. The involvement of African pastoralists in leather industry and commerce can also be deduced from the recurrence of leather products in the Zarai tariff. 61 Moreover, comparative evidence from the northern frontier confirms the high demand for hides and leather and the reliance on tribes along the frontier to organize supplies. ${ }^{62}$ Tacitus for instance relates how the Frisons, a subdued nation living beyond the Rhine, had to deliver ox skins for military uses. ${ }^{63}$ In Vindolanda, hundreds of hides were being delivered to the garrison for further processing. ${ }^{64}$ The fort and the vicus of this site also provide the single largest concentration of Roman leather in Britain. However, the fact that most of these products are archaeologically virtually invisible hampers the analysis of these exchange patterns.

\section{Civilian Markets}

Second, civilian markets also benefitted from the fact that pastoral economies always are a major provider of raw materials for the textile industry (see Figure 6.1 and Figure 6.2). We already mentioned the importance of leather, but the Zaraï tariff also notes the exchange of woolen fleeces (pellem ovellam). Wool provisioning by pastoralists definitely proved to be very advantageous for arable agriculture, because animal husbandry often set high demands on estate-owners. The animal needs included sufficient grazing lands, water resources and shelter, which, especially in arid and semi-arid climate zones, few environments could provide throughout the year. The competition

59 Peter Herz, "Der Aufstand des Iulius Sacrovir," Laverna 3 (1992), pp. 42-93.

6 o <http://vindolanda.csad.ox.ac.uk/exhibition/army-4.shtml> (accessed on 09/12/13).

$61 \quad C I L$ 8, 4508 (lex coriaria).

62 Carol van Driel-Murray, "The Production and Supply of Military Leatherwork in the First and Second Centuries AD: a Review of the Archaeological Evidence," in The Production and Distribution of roman Military Equipment, ed. M.C. Bishop (Oxford, 1985), pp. 43-81.

63 Tac. Ann. $4 \cdot 72$.

$64 A E$ 1990, 671. Alan K. Bowman, J. David Thomas, and James N. Adams, The Vindolanda writing-tablets (tabulae Vindolandenses II) (London, 1994), pp. 321-329. 
between animals and cash crops for space and water may thus work out badly for sheep. However, with flocks of sheep being kept by semi-nomads ensuring a regular water supply during summer by transhumance and wool apparently being exchanged in more urbanized regions, there was no need to allocate a considerable part of the available agricultural land to sheep-rearing and growing fodder in a mixed agriculture. Instead, as part of the raw materials would be imported by pastoralists, estate-owners had the opportunity to specialize in the production of goods destined for the Mediterranean markets and Rome in particular, viz. wine, oil and grain.

Civilian markets possibly also obtained wild animals from the Garamantes, although the trans-Saharan journey naturally seems to be a major obstacle for many sub-Saharan species. ${ }^{65}$ Nevertheless, a few texts provide evidence for a Garamantian role in the trade in wild beasts and their secondary products. The geographer Ptolemaeus commemorates the journey of a certain Iulius Maternus, otherwise unknown, who travelled with the Garamantian king to a destination called Agisymba, a name which appears to be a bantu phrase meaning 'land of the lion'.66 The discovery within Garamantian territory of bracelets made of ivory may point to the presence of a local ivory industry. 67 Moreover, a trans-Saharan ivory trade may have been stimulated by the rapid decline in northern Africa of the elephant population, due to a combination of increasing climatic desiccation and excessive hunting. ${ }^{68}$

\section{The Sub-Saharan Markets}

Turning now to the markets in the south, we again argue that the range of products exported by the Garamantes to the sub-Saharan kingdoms may have

65 For the trade in African animals, see François Bertrandy, "Remarques sur le commerce des bêtes sauvages entre l'Afrique du Nord et l'Italie (II ' s. av. J.C.-IV e s. ap. J.C.)," Mélanges de l'École française de Rome. Antiquité 99, no. 1 (1987), pp. 211-241.

66 Ptol. 1, 8, 4. On the bantu phrase, cf. Serena Bianchetti, "Esplorazioni africane di età imperiale (Tolomeo, Geogr., I, 8, 4)," in In: L'Africa romana. Atti dell'XI convegno di studio (Cartagine, 1994), eds. Mustapha Khanoussi, Paola Ruggeri and Cinzia Vismara (Sassari, 1996), pp. 355-356.

67 Mattingly, "The Archaeology of Fazzān. Vol. I. Synthesis," p. 360.

68 Lucianus (De Dips. 2) mentions elephant hunting by the Garamantes. Diminishing ivory supplies are noted by Pliny (N.H. 8, 7). Elephants were however not completely absent from North Africa (Plin. N.H. 5, 5 and 12 and also18 and 26 + 8, 31-32 and 35; Strabo 17, 3, 4-5 and 7-8; Front., Strat. 4, 7, 18; Aelian. N.A. 14, 5-6; Pomp. Mela Chor. 3, 104). Elephant tusks as votive gifts: IRT 295 and $I R T 231$ (from Lepcis Magna and Oea, respectively). 
included other merchandise than salt alone (see Figure 6.3 and Figure 6.4). It has already been noted that foodstuffs, textiles and beads produced in Garamantian territory eventually reached the sub-Saharan regions, but we probably have to revise the scale of these commercial contacts. ${ }^{69}$ The recent archaeological project at Kissi (Burkina Faso) can be a good case in point.

According to the traditional triangular trade model, this region was mainly exporting gold from the Sirba gold fields and probably also (the archaeologically less visible) black slaves to northern markets in exchange for a large variety of goods. The sub-Saharan kingdoms probably closely cooperated with the Garamantes in the procurement of sufficiently large quantities of slaves,

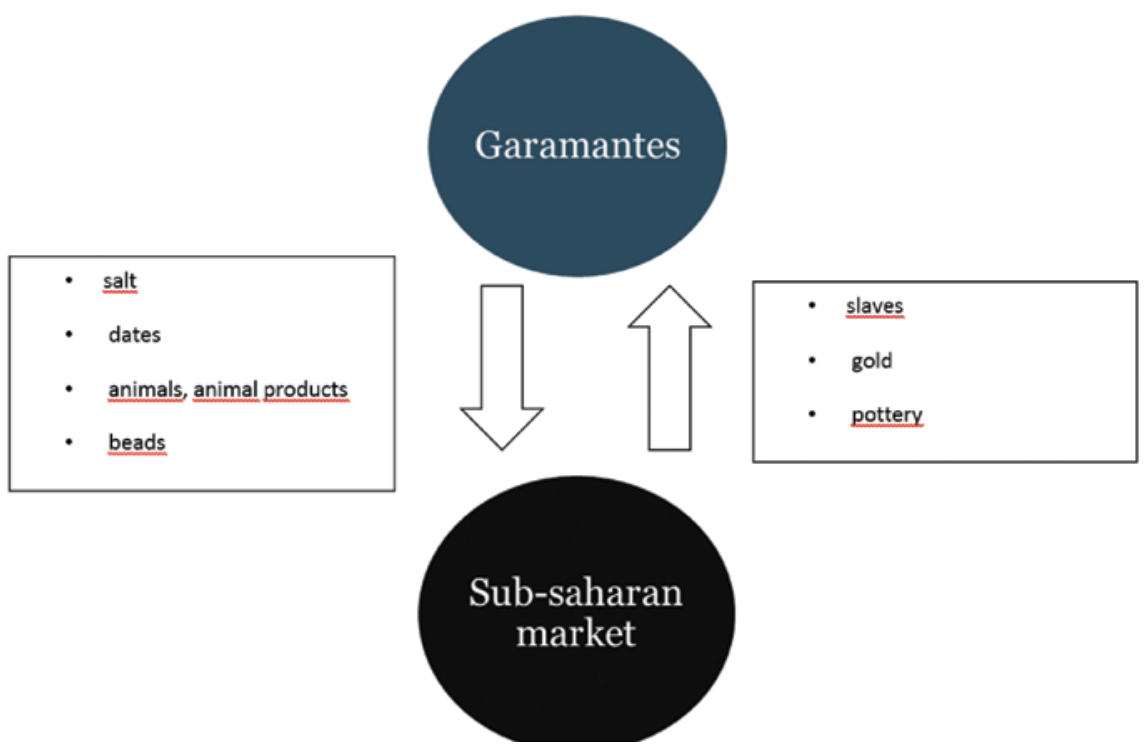

FIGURE 6.3 Exchange with southern regions.

69 Mattingly, "Early Libyan State with Trans-Saharan Connections," p. 57. MacDonald lists the potential trading partners in the south. Kevin C. MacDonald, "Sub-Saharan Evidence for Contacts between North Africa, Mauritania and the Niger, 1000 BC-AD 700," in Money, Trade and Trade Routes in Pre-Islamic North Africa, eds. Amelia Dowler, Elizabeth R. Galvin (London, 2011), pp. 72-82. Though dated to ca. 500 вC, the fortified settlement of Zilum near Lake Chad in North-East Nigeria forms an example of the possible southern markets of the trans-Saharan trade a few centuries later. Cf. Carlos Magnavita et al., "Zilum: a MidFirst Millennium BC Fortified Settlement near Lake Chad" Journal of African Archaeology 4 (2006), pp. 153-170. 


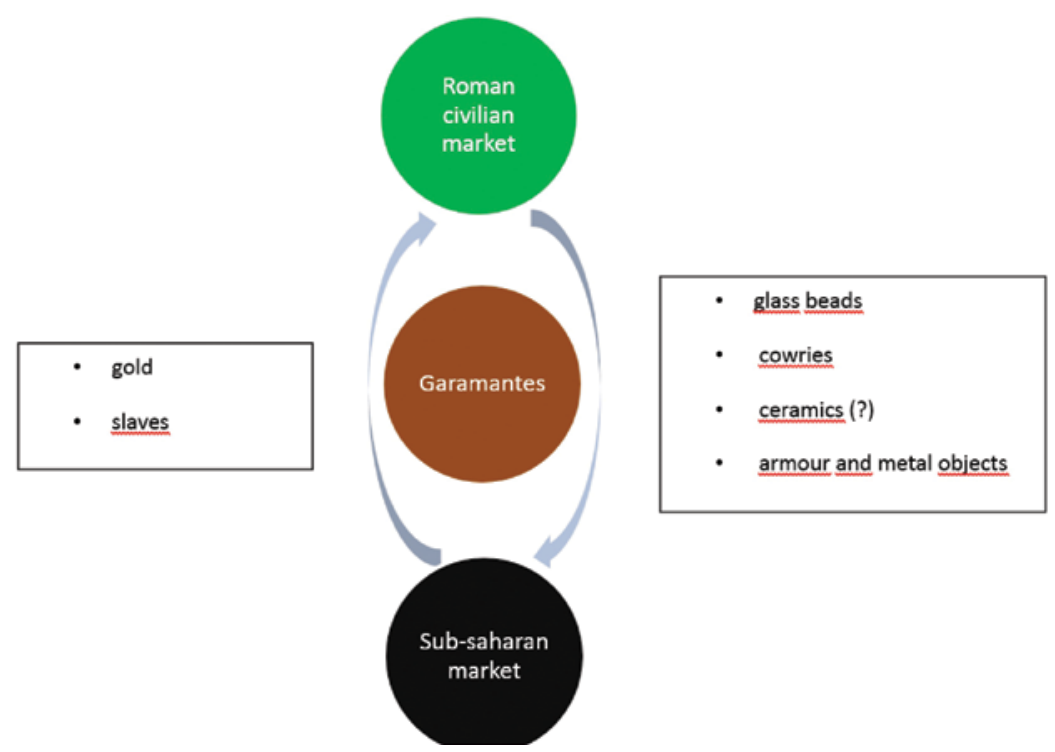

FIGURE 6.4 Mediatory trade between North Africa and Sahel.

for Herodotos already mentions Garamantian slave raids in the land of the Troglodytes. ${ }^{70}$ Rock drawings in the same territory seem to confirm this claim, as they clearly depict slave hunts by ancestors of the Garamantes. ${ }^{71}$ Part of the captured slaves never left Garamantian territory and were used for dangerous tasks, such as the construction of underground foggaras, but others were re-exported to Roman markets. ${ }^{72}$ Swanson's hypothesis that "the Roman empire apparently had no need for slaves from the western Sudan" because

70 Her. Hist. 4, 183, 4.

71 See for instance the scene of a pursuit carved on rocks at Oued Djerat, Henri Lhote, "Les chars rupestres du Sahara et leurs rapports avec le peuplement dans les temps protohistoriques," in Les chars préhistoriques du Sahara. Archéologie et techniques d'attelage. Actes du colloque à Sénanque, 1981, eds. Gabriel Camps, Marceau Gast (Aix-en-Provence, 1982), p. 24; Henri Lhote, Les chars rupestres sahariens des Syrtes au Niger, par le pays des Garamantes et des Atlantes (Toulouse, 1982), p. 108. The forticifation of ancient sub-Saharan settlements may be linked with these pre- and proto-historic raids. Magnavita et al., "Zilum: a Mid-First Millennium BC Fortified Settlement Near Lake Chad," pp. 153-170.

72 Mattingly, "The Archaeology of Fazzān. Vol. I. Synthesis," pp. 276 and 36o. David J. Mattingly, “Nouveaux aperçus sur les Garamantes: un État saharien?," Antiquités africaines 37 (2001), p. 57. The import of black slaves may be suggested by the epigram on the black slave called "faex Garamantum" at Hadrumetum: Franz Bücheler and Alexander Riese, eds. Anthologia Latina sive poesis Latinae supplementum (1894-1897), nr. 183. According to 
"they were readily available in large quantities throughout the empire" can hardly convince. ${ }^{73}$ Apart from the constant need for slave labor and the particular skills sub-Saharan slaves may have possessed (labor in extreme weather conditions), their distant origin and physique created additional value on the slave market, which encouraged masters to pay higher prices and treat their slaves as status objects. ${ }^{74}$

A first candidate for regular imports to sub-Saharan settlements were textiles. Even though funerary contexts in Kissi contained remains of textiles possibly as early as the 1st century $\mathrm{BC}$, equipment to manufacture these textiles have not yet been discovered during the excavations. ${ }^{75}$ One could argue that these woolen textiles may have been produced by hand, yet the rarity of wool producing animals such as camels, dromedaries and sheep in the region before the Arabic period must point to the imported nature of the goods or the raw material. ${ }^{76}$ Particularly interesting in Kissi are the huge quantities of beads, made of glass, stone, metal, bone and shells. ${ }^{77}$ Most siliceous stone beads and metal beads can be assigned to local production areas in Mali and the Niger valley region, but others had been manufactured in more distant regions. Glass was probably produced among the Garamantes, either by recycling imported vessels or by using local sources of natron in their territory. Chemical analysis of the glass beads suggests the raw material, and maybe the finished product as well, had been imported from the Near or Middle East, although Diodorus Siculus mentioned the presence of natron in the inlands beyond Cyrene. ${ }^{78}$

Law, the epigram "equally indicates that this was unusual". Law, "The Garamantes and Trans-Saharan Enterprise in Classical Times," p. 196.

73 Swanson, "The Myth of Trans-Saharan Trade during the Roman Era," p. 596.

74 Walter Scheidel, "Human Mobility in Roman Italy, II: The Slave Population," Journal of Roman Studies 95 (2005), p. 67.

75 Sonja Magnavita, "The Oldest Textiles from Sub-Saharan West Africa: Woolen Facts from Kissi, Burkina Faso," Journal of African Archaeology 6 (2008), p. 244.

${ }_{7} 6$ Sonja Magnavita, "Sahelian Crossroads: Some Aspects on the Iron Age Sites of Kissi, Burkina Faso," in Crossroads: Cultural and technological developments in first millennium $B C / A D$ West Africa, eds. Sonja Magnavita et al. (Frankfurt-am-Main, 2009), pp. 88-91; Magnavita, "The Oldest Textiles from Sub-Saharan West Africa: Woolen Facts from Kissi, Burkina Faso," pp. 246 and 250.

77 Magnavita, "Sahelian Crossroads: Some Aspects on the Iron Age Sites of Kissi, Burkina Faso," pp. 85-86 and 9o-91. Sonja Magnavita, "The Beads of Kissi, Burkina Faso," Journal of African Archaeology 1 (2003), pp. 127-138.

78 Diod. Sic. 3, 50, 1. For glass production among the Garamantes, cf. Mattingly, "The Archaeology of Fazzān. Vol. I. Synthesis," p. 121 (Jarma area), p. 125 (al-Hitaya oasis). Mattingly, "The Archaeology of Fazzān. Vol. III. Excavations carried out by C.M. Daniels," p. 197 (Saniat Jibril), also pp. 413-458. For the availability of natron in their territory: 
Some of the bead sizes, colors and shapes even resemble comparable production in India and Sri Lanka. ${ }^{79}$ The existence of this trans-continental trade route is also confirmed by the discovery of cowries or snail shells originating from somewhere between the Red Sea to the South-Pacific in two graves, which must have reached Kissi together with the beads. ${ }^{80}$ Carnelian beads too must certainly have been imported. The excavators' report pretty vaguely places the origin in an area 'beyond the desert'.81 Yet, this semi-precious stone was a renowned Garamantian export product and hence an indicator of trans-Saharan exchange. ${ }^{82}$ The standardized nature of these objects can even suggest mass-production by skilled artisans and a large-scale carnelian bead industry in the Garamantian territory. ${ }^{83}$ Part of this local African bead production eventually reached the Roman market as well, so the Garamantes may also have extended their mediatory role in the bead trade to the northern

Mattingly, "The Archaeology of Fazzān. Vol. I. Synthesis," pp. 359-360. Transcontinental imports at Kissi, cf. Peter Robertshaw et al., "Glass Beads from Kissi (Burkina Faso): Chemical Analysis and Archaeological Interpretation," in Crossroads: Cultural and technological developments in first millennium BC/AD West Africa, eds. Sonja Magnavita et al. (Frankfurt-am-Main, 2009) pp. 105-118. The earliest glass beads have been found in graves dated to the 1st-3rd century AD. Large quantities occur in graves dated before the 8 th century AD. Cf. Magnavita, "The Beads of Kissi, Burkina Faso," p. 134. Glass beads were regular grave gifts among the Garamantes as well. Cf. Mattingly et al., "Desert migrations: people, environment and culture in the Libyan Sahara," p. 144.

79 Magnavita, "Sahelian Crossroads: Some Aspects on the Iron Age Sites of Kissi, Burkina Faso," pp. 92-94. Magnavita, "The Beads of Kissi, Burkina Faso," p. 133.

80 Magnavita, "Sahelian Crossroads: Some Aspects on the Iron Age Sites of Kissi, Burkina Faso," p. 94. These finds refute previous claims that cowrie-shells of this type did not reach West Africa in the first millennium A.D. Sutton, "West African metals and the ancient Mediterranean," p. 184.

81 Magnavita, "Sahelian Crossroads: Some Aspects on the Iron Age Sites of Kissi, Burkina Faso," p. 92. Magnavita, "The Beads of Kissi, Burkina Faso", p. 130.

82 Plin. N.H. 37, 92 and 37, 104; Strabo 17, 3, 11 and 19; Plin. N.H. 5, 37.

83 Fragments of carnelian (possibly the 'Garamantian carbuncles' or 'Carthaginian stones', a name identifying the primary trade route) and other semi-precious stones as well as tools to shape and polish beads regularly occur in Garamantian territory. See Mattingly, "The Archaeology of Fazzān. Vol. I. Synthesis", pp. 118-120 (Jarma area), pp. 125-126 (al-Hitaya oasis), pp. 356-358 (overview). Mattingly, "The Archaeology of Fazzān. Vol. III. Excavations carried out by C.M. Daniels," pp. 189-194 (Saniat Jibril), beads pp. 458-470 and tools (bead grinders) pp. 470-474. Similar evidence is available for the Watwat cemeteries and Ghirza: Mattingly et al., "Desert migrations: people, environment and culture in the Libyan Sahara," p. 144. and Brogan and Smith, "Ghirza. A Libyan settlement in the Roman period," p. 243. 
African regions. ${ }^{84}$ Bead analysis thus reveals that considerable amounts must have been brought to Kissi from the Garamantian territory and, via Egypt, from the Near East. It seems very likely that commerce along both trade routes was being organized by Garamantian trans-Saharan entrepreneurs, who specialized in exporting own produce and redistributing imported merchandise to western Africa. ${ }^{85}$

Long-distance trade is also suggested by the metallurgical analysis of several metal objects discovered in grave contexts in Kissi. A pair of anklets, dated to the $5^{\text {th }}-7^{\text {th }}$ centuries, was made of brass, an alloy of copper and zinc. As this production technique has not been attested in western Africa before the 2nd millennium $\mathrm{AD}$, the objects or at least the metal must have been produced elsewhere. ${ }^{86}$ Isotopic ratios are not conclusive to determine the exact origin of the ore, but certainly exclude African sources. ${ }^{87}$ Moreover, the import of brass objects, ingots and/or rods clearly predates the $5^{\text {th }}$ century, for older graves belonging to a time-span between the ist c. $\mathrm{BC}$ and the 4 th $\mathrm{c}$. AD already yielded a brass anklet and bracelet. ${ }^{88}$ Chemical analysis of these two objects suggests the ores originated from Sardinia or southern France. ${ }^{89}$ Early imports of merchandise produced in distant regions are also indicated by fragments

84 The gems possibly originate from the Tibesti area. Plin. N.H. 5, 34.

85 Contra John E.G. Sutton, "Igbo-Ukwu and the Nile," African Archaeological Review 18, no. 1 (2001), pp. 49-62 (esp. p. 52). Sutton argues in favor of routes of commerce between the Nigerian rainforest and Egypt via the Chad Basin.

86 Similarly, Sutton found a brass bracelet in the region of Agades dating to ca. 500 BC and likewise stressed its Mediterranean provenance. Sutton, "West African metals and the ancient Mediterranean," p. 185. It is interesting to note that a North African source of calamine, which is needed to produce brass, has been identified in the Segermes area. Cf. Peter Ørsted, "Part III: Production and Population," in Africa Proconsularis. Regional Studies in the Segermes Valley of Northern Tunisia, eds. Peter Ørsted et al. (Gylling, 200o), pp. $160-161$.

87 Thomas R. Fenn et al., "Contacts Between West Africa and Roman North Africa: Archaeometallurgical Results from Kissi, Northeastern Burkina Faso," in Crossroads: Cultural and technological developments in first millennium BC/AD West Africa, eds. Sonja Magnavita et al. (Frankfurt-am-Main, 2009), p. 128. Copper was nevertheless produced in some regions in North Africa, such as Numidia. Cf. Strabo 17, 3, 11, who somewhat counters the apparent absence of North African copper mentioned by Lucan, Phars. 9, 424-425. Possibly, production levels were fairly low. Swanson, "The myth of trans-Saharan trade during the Roman era," p. 589 .

88 Magnavita, "Sahelian Crossroads: Some Aspects on the Iron Age Sites of Kissi, Burkina Faso," p. 91.

89 Fenn et al., "Contacts Between West Africa and Roman North Africa: Archaeometallurgical Results from Kissi, Northeastern Burkina Faso," p. 127. 
of armor and weaponry. Several small cuprous rings, probably part of a chainmail, closely resemble comparable 3rd-century Mediterranean armor. Chemical analysis confirmed their foreign origin, for the metal alloy of the rings had been produced in the western Mediterranean. Isotopic analysis shows a strong correspondence with Spanish ores, although an origin from Sardinia and even Britain cannot be ruled out. ${ }^{90}$ Additionally two iron swords were found in $5^{\text {th }}-7$ th century graves, which, although the exact location of production is unknown, were either imported or produced locally with previously imported swords as prototypes. At any rate, the chainmail and swords can easily be identified as foreign decorative or status objects, demonstrating the prestige and wealth of their possessor. ${ }^{91}$ The fact that trans-Saharan merchants were well-aware of the potential value of these exotic goods may stress the regularity of commercial contacts. In conclusion, the combination of archaeological and chemical analysis clearly reveals the import of non-African ores, bars, rods and/or metal objects to Kissi. It is possible merchants were supplying a combination of finished objects and raw material, which at various nodes of the trade network and even at the end of the trans-Saharan route could be mixed with local ores and processed into whatever objects were in demand. This production process of mixing and assembling ores can explain why the chemical analysis of some simple every-day objects such as bracelets and anklets was sometimes unable to pinpoint an exact origin. ${ }^{92} \mathrm{On}$ the other hand, objects such as the chainmail, whose exotic origin mainly reflected status and affluence, were more likely imported as finished goods, produced in the Mediterranean area and with a clear isotopic ratio of a particular mining area. Comparable isotopic analysis of other African metal objects show many correspondences between the Kissi artifacts and the objects found in Carthage and Tunisia from the Punic and Roman period. ${ }^{93}$ They apparently must have shared a common 'trade pool' of ores, mainly originating from the western Mediterranean. This merchandise was thus probably following caravan routes south from Carthage to the Hoggar and the Agadez region of Niger, where goods were being reconfigured for east-west trade. From the Niger valley, goods eventually reached the Kissi region. Given that the Garamantes had clear commercial contacts with Carthage, we may again hypothesize that the

\footnotetext{
$90 \quad$ Ibid., pp. 126-127.

91 Magnavita, "Sahelian Crossroads: Some Aspects on the Iron Age Sites of Kissi, Burkina Faso," pp. 91-92 and 96.

92 Fenn et al., "Contacts Between West Africa and Roman North Africa: Archaeometallurgical Results from Kissi, Northeastern Burkina Faso," pp. 130 and 136-137.

93 Ibid., pp. 130-133.
} 
trans-Saharan trading networks linking the north-African coastal regions with south-Saharan regions were dominated by Garamantian entrepreneurs.

Finally, as the Garamantes were practically living in the center of a broad range of commercial networks, they were at least able to re-export part of the Mediterranean goods acquired in exchange for the merchandise transported into Roman territory. The Mediterranean ceramics found in Garamantian graves offer a good example for the kind of alien objects crossing the border, probably in the first place as luxury items. ${ }^{94}$ During the late 1 st and early 2nd century $\mathrm{AD}$, the period of the highest concentration of imported grave goods, Mediterranean vessels appear to have reached the Garamantian territory in small batches, pointing to a rather early take-off in trade with the cities along the Mediterranean coast. ${ }^{95}$ Italian and Gallic sigillata dominate the collections during this period. ${ }^{96}$ Interestingly, African pottery with "tribal" or "Saharan" themes appear in North Africa in the later Roman period, suggesting a mutual exchange of production techniques or at least familiarity with decorative motives favored in more southern regions. ${ }^{97}$ Amphorae finds include shreds of late Greco-Italic and Dr. 1 wine amphorae, Tripolitanian wine and oil

94 General overview in Mattingly, "The Archaeology of Fazzān. Vol. I. Synthesis," pp. 227-232. For a more southern settlement, see Liverani, "Looking for the Southern Frontier of the Garamantes." For the import of high-quality glass vessels and faience, see Mattingly, "The Archaeology of Fazzān. Vol. II. Site Gazetteer, Pottery and Other Survey Finds," p. 485.

95 Mattingly, "The Archaeology of Fazzān. Vol. III. Excavations carried out by C.M. Daniels," pp. 526-529.

96 Italian and Gallic pottery: Mattingly, "The Archaeology of Fazzān. Vol. II. Site Gazetteer, Pottery and Other Survey Finds," pp. 331-332. and Mattingly, "The Archaeology of Fazzān. Vol. III. Excavations carried out by C.M. Daniels," p. 165 (Saniat Jibril). A detailed analysis of the pottery in the region is offered by Mattingly, "The Archaeology of Fazzān. Vol. II. Site Gazetteer, Pottery and Other Survey Finds," pp. 305-425. See also Mattingly, "The Archaeology of Fazzān. Vol. III. Excavations carried out by C.M. Daniels," pp. 222-341 for Saniat bin Huwaydi graves. This trade pattern with the Mediterranean area appears to have been disrupted during the third century, when the port cities faced economic decline, a rapidly decreasing demand for slaves and change in levels of connectivity. At the same time, imports of Mediterranean merchandise to the Garamantian territory were seriously reduced from the late third century onwards. This period coincides with the appearance of qsur or castles in Wadi al-Ajal, pointing to a less secure society and trading world. For this chronological evolution, see Mattingly, "The Archaeology of Fazzān. Vol. I. Synthesis," pp. 277 and 349 .

97 Increased contact in the pottery industry may lay at the origin of the depiction of tribal and Saharan themes on African sigillata, cf. Sergio Fontana, "Tradizione artigianale e raffigurazione di tipi etnici nei balsamari configurati di produzione africana (III-IV sec. d. C.)," Quaderni di archeologia della Libia 17 (1995), p. gof. 
amphorae and Late Roman wine amphorae. ${ }^{98}$ These may have been the kind of wine amphorae mentioned in the Zaraï and Lambaesis tariffs. It is interesting to note that several items show the same potter's stamp and graffiti, suggesting they at one time had belonged to the same collection of objects. The arrival of Mediterranean ceramics in the African port cities is probably to be connected with the Roman food supply (annona), for the grain ships returning from Ostia often filled the hold with low-value and easily stackable objects to quickly return to Africa and start another voyage. ${ }^{99}$ The grave goods indeed show a remarkable preference for large open forms of both glass vessels and ceramics, which are very easy to store in the hold. ${ }^{100}$ The presence of Roman ceramics and amphorae among the grave gifts shows these objects were destined for local consumption by the Garamantes themselves, but the status of rather rare, exotic luxury items made them perfectly suitable for re-export to more remote tribes, who only interacted with the Mediterranean area via commercial contacts with Garamantes and other nomads. Moreover, an opposite movement of pottery of sub-Saharan origin to Garamantian territory can be traced, suggesting pottery and ceramics did indeed qualify as commercial goods. ${ }^{101}$

\section{Conclusion}

The analysis of cross-border commercial contacts between nomadic and sedentary societies in Roman North Africa clearly suggests that previous studies have underestimated both the scope and scale of exchange controlled by pastoral tribes such as the Garamantes. ${ }^{102}$ Ongoing archeological surveys now

98 Mattingly, "The Archaeology of Fazzān. Vol. II. Site Gazetteer, Pottery and Other Survey Finds," pp. 310-311 and 336-363.; Mattingly, "The Archaeology of Fazzān. Vol. III. Excavations carried out by C.M. Daniels," pp. 167-168 (Saniat Jibril).

99 Christian Rico, "La diffusion par mer des matériaux de construction en terre cuite : un aspect mal connu du commerce antique en Méditerranée occidentale," Mélanges de l'École française de Rome. Antiquité 107 (1995), pp. 767-80o.

100 Mattingly, "The Archaeology of Fazzān. Vol. I. Synthesis," p. 229.

101 Liverani, "Looking for the Southern Frontier of the Garamantes," p. 37. Maria C. Gatto, "The Local Pottery," in Aghram Nadharif. The Barkat Oasis (Sha'Abiya of Ghat, Libyan Sahara) in Garamantian Times, ed. Mario Liverani (Firenze, 2005), pp. 239-240.

102 The monopoly of the Saharan peoples in this trade system has been underscored by biodistance studies based on cranial traits of human remains. A recent survey concludes that there was no biological interaction between the Garamantes and outsiders (originating from the Mediterranean world, Egypt or Meroe). Nikita, Mattingly, and Mirazon Lahr, 
allow a reassessment of the traditional triangular trade patterns and begin to stress, first, the economic value of merchandise produced by the pastoralists themselves, in particular for the military markets along the frontier, and second, the wide range of goods transported by the nomads in a mediatory trade model to the northern and southern markets alike. The nomadic tribes must therefore be considered valuable economic partners promoting interaction and exchange between otherwise isolated regions and deliberately capturing the benefits long-distance trade had to offer, rather than small-scale entrepreneurs only occasionally engaging in commercial exchange.

"Sahara: Barrier of Corridor? Nonmetric Cranial Traits and Biological Affinities of North African Late Holocene Populations." Unfortunately, the study did not include individuals from sub-Saharan regions. 